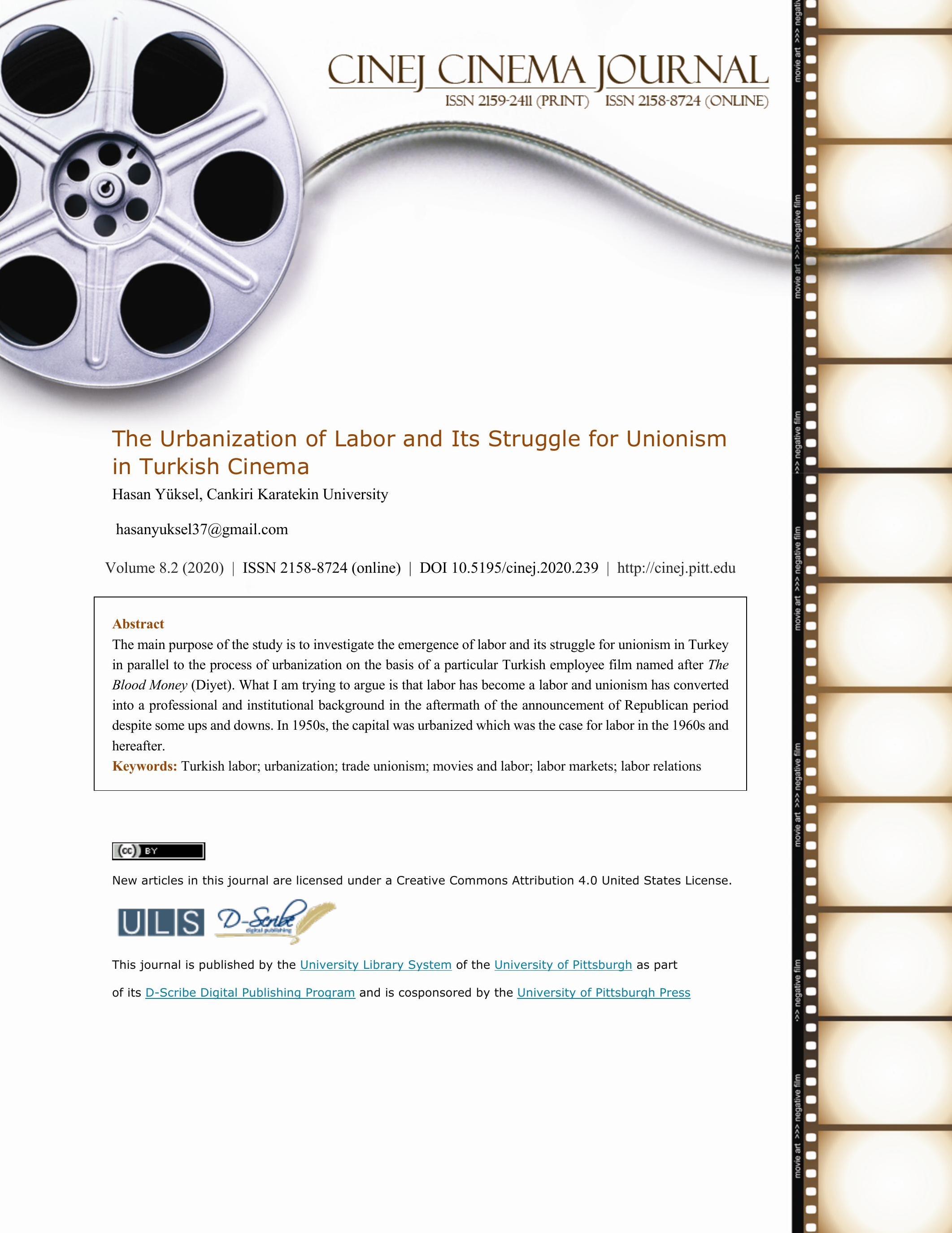




\section{The Urbanization of Labor and Its Struggle for Unionism in Turkish Cinema \\ Hasan Yuksel}

\section{Introduction}

Most of the research regarding labor markets has been conducted through the use of reallife data or investigation. This study follows a different format and analyzes the dynamics of the formation of Turkish labor unionism by means of a particular film, The Blood Money (Diyet, 1975) by Ömer Lütfi Akad.

Films, as do all other media apparatuses, display a certain image and convey a particular social, political, and cultural message to the audience (Agha 2007; Agha 2011: 163-170; Johnson and Astrid 2007; Hiramoto and Joseph 2010: 179-188). Taking into account the fact that films, just like other artistic creative outputs like books, novels, poems, theatre plays and songs, reflect the conditions of their era in which they were produced, I analyze the process of how Turkish labor and its struggle to establish trade unions is represented through this film. The formation of trade unions in Turkey is a long and intricate story and it has become an issue which was directly dealt with by filmmakers, especially by those who were the supporters of social realism in Turkish cinema. $^{1}$

For theoretical and practical implications of the research, I adapt discourse analysis approach and their reflections of different genres by Hodges, Kuper, and Reeves et al. (2008: 570572), Barton (2002: 575-594), Madichie (2011: 169-197), Walton and Boon (2014: 351-370). In addition, I use a professional data analysis program, MAXQDA 2018, to unravel the main framework for the investigation of the discursive content of the movie, which makes this study unique. 
At first, I conducted a detailed research on the films that deal with purely the problem of unionism of Turkish labor through search engine Google. Search words such as "labor movies in Turkey", "unionism and movies in Turkey", "social realism and Turkish labor movies", "film studies and Turkish labor" were utilized. I realized that the movie Blood Money (Diyet) is quite popular and interesting concerning the message given to the labor and to the community within the framework of trade unionism and the urbanization of labor. After that, I watched the film over and over and I examined the film script and I categorized the content of the movie based upon three parameters: unionism (i), labor (ii), and urbanization (iii) which are also the codes written in MAXQDA as well. Unionism is the first parameter as the movie mainly focuses on this issue. On the other hand, Turkish labor and unionism and urbanization as the reasons for Turkish labor emanation, are grappled in the film. Under the code word of unionism, I created ten different sub codes such as strike, multiply, wage increase, bargaining, unite, human right, collective, daily wage, law, and trade union. As for the code word of labor, seventeen sub codes were written like laborer, contract, weekly wage, farm laborer, order, employee, bread, overtime, compensation, onthe-job, job accident, factory, money, Turkish lira, machine, work, and master. Lastly, penthouse, land, apartment, contractor, Istanbul, floor, village, city, furnace, homesickness, roof, door, hometown, and home are the sub codes created for the code word of urbanization.

Moving from three essential codes, I find that the film is fundamentally centered upon labor unionism and the formation/urbanization of Turkish industrial labor. The urbanization is the path that paves the way for emergence of the industrial labor itself. The research questions of the paper are thus as in the following:

RQ1. How do labor films depict the labor identity formation and labor unionism?

RQ2. What are the sine quanon of trade unionism in Turkey? 
RQ3. Is it possible that the films can be utilized for labor market studies?

Hence, the study consists of three parts. In the first part of the study, the topic of urbanization within the framework of labor and its contribution to the formation of labor is uncovered. Secondly, the historical perspective of labor unionism in Turkey including preRepublican and Post Republican period is also mentioned. The methodology of the research and the findings obtained via MAXQDA are the issues unveiled in the third part of the study.

\section{Literature Review}

In this chapter of the research, the urbanization of labor generally as well as Turkish case study and Turkey's journey towards unionism have been mentioned. As urbanization of labor and trade unionism in Turkey are at the heart of the empirical section of the study, it is important have a look at their theoretical backgrounds.

\section{The Urbanization of Labor in the World}

In this part of the research, the urbanization process and its connection with the industrial labor will be discussed in line with the empirical aspect of the study. Throughout history, labor has been exposed to some radical transformations. In primitive societies, labor was naturalized; it was enslaved during slavery; in agricultural economy and feudal era, it was ruralized; in the period of modern industry, it was industrialized, mechanized and urbanized professionally; and at last, labor was digitalized in knowledge societies.

Industrialization is a way for labor transfer from agricultural areas to the industrial zones, which also accelerates the urbanization of the economy (Lewis, 1954: 139-191 and Bairoch, 1988). In many cases, industrialization and urbanization go hand in hand (for the connection between industrialization and urbanization see also Jiang and Lin, 2012: 608-615; Harris, 1971: 102-124; 
Claval, 1988: 27-38; Goldstein and Goldstein, 1984: 90-110; Reiss, 1954: 27-29; Moir, 1976: 123 -

135; McHale and Johnson, 1977: 210-247; Hagedom Miller and Labovitz, 1971: 177-195; Scott, 1986: 25-37; Lewis, 1989: 628-634; Mokyr, 1980; Walton and Sween, 1971: 721-745; Bodenhorn and Cuberes, 2018: 47-58) because the former fosters the latter.

The urbanization of labor, which is crucial resource for social change in emerging economies (Speare et al., 1988: 919), is closely connected with the process of industrialization as stated by Williamson (1991) in his argument: "Successful industrialization always fosters urbanization.” (Williamson, 1991: 241). Of course, the interconnection between industrialization and urbanization is to be demonstrated with economic growth in parallel to the mass production and mass population activities. The population is urbanized because of urbanized industry (Huff and Angeles, 2011: 20, 21).

In the literature, there are a great many studies that explain the correlation between industrialization and urbanization as both are assessed as interdependent processes for modern economic development. As a matter of fact, the relationship between industrialization and urbanization is clarified and symbolized through the invention of steam engine that enhanced the shift from manufacturing from hand and hydro power to steam power. For example in the US, the industrialization began in the second half of the nineteenth century, and the domestic labor force rose from 10 to $20 \%$ between 1850 and 1880 which is in line with the share of the population in urban areas that went up from 15 to $30 \%$ (Sukkoo, 2005: 586).

According to Rosenberg and Trajtenberg (2004), the usage of steam engine by manufacturers, especially the Corliss engine, accelerated the process of urbanization due to the fact that it released the firms from locational limitations like topography and climate and it offered 
the manufacturers to locate in the cities. With the contribution of Corliss steam engine, the agglomeration economies emerged (Rosenberg and Trajtenberg, 2004: 61-99).

In his early modern capitalism, Braudel (1967) were on the idea that steam engine, that is to say, industrialization created steam engine towns. He compared steam engines with the clocks and he categorized cities as steam engine towns and clock towns to lay an emphasis on the fact that the cities, in which steam engines were quite dominant, were the early representations of capitalism since they were the places where ceaseless economic transactions took place which also augmented the rhythm of the city and the lives' of men. However, clock towns are the ones which were "long, straight, and unbroken line across time." (Braudel, 1967: 396, 397).

Davis (1965) regards the commencement of urbanization with the beginning of industrialization. His ideas sheds light on the fact that there was no community or a society described as "urbanized" before 1850 and by 1900, just Great Britain was considered in this category although small cities appeared 5,500 years ago. Today, as everything has been in an ongoing and quick alteration, the concept of urbanization also changed. In this context, all the industrial nations were referred as urbanized. This urbanized way of life stemming from industrialization dictated different way of life as the urban population involves a special human contact that created another social confusion that has never been witnessed. Now, people were more crowded than any other animal community, and urban life forced people behave like "communal insects" rather than "mammals" (Kingsley, 1966: 4).

In addition, Blumin (2006) makes a reference to "urban revolution" to indicate the spheres of urbanization and while delineating his ideas, he gets benefit from Weber and his perspectives. Weber, in his American manifestation, stresses that urbanization is a universal and global event since urban areas occur as a result of the same reasons, and in an identical way all over the world. The cities are interconnected regionally, nationally, and internationally. Particularly, cities and 
urban areas enlarged promptly during nineteenth century in the West including England and Wales, France and the United States. Weber referred this concentration of the population via the term "take off" and he tried hard to find an answer to this question: "Why did people emigrate to the urban areas and what were the motivational tools for these actions in all parts of the world?" The answer was quite simple: "Steam". Therefore, Weberian ideology supported the notion that industrialization caused urbanization which forward-facing businessman were investing on smoky industries (Blumin, 2006: 47, 48).

Table 1. Changing Concentration of Population in Nineteenth Century in Different Locations of the World

\begin{tabular}{|c|c|c|}
\hline \multicolumn{3}{|c|}{ England and Wales } \\
\hline \multirow[t]{2}{*}{ Living in cities greater than 10,000} & 1801 & $21 \%$ \\
\hline & 1891 & $62 \%$ \\
\hline \multirow[t]{2}{*}{ Living in cities greater than 100,000} & 1801 & $10 \%$ \\
\hline & 1891 & $33 \%$ \\
\hline \multicolumn{3}{|c|}{ France } \\
\hline \multirow[t]{2}{*}{ Living in cities greater than 10,000} & 1801 & $10 \%$ \\
\hline & 1891 & $26 \%$ \\
\hline \multirow[t]{2}{*}{ Living in cities greater than 100,000} & 1801 & $3 \%$ \\
\hline & 1891 & $12 \%$ \\
\hline \multicolumn{3}{|c|}{ United States } \\
\hline \multirow[t]{2}{*}{ Living in cities greater than 10,000} & 1790 & $3 \%$ \\
\hline & 1890 & $28 \%$ \\
\hline \multirow[t]{2}{*}{ Living in cities greater than 100,000} & 1790 & $0 \%$ \\
\hline & 1890 & $15 \%$ \\
\hline
\end{tabular}

Source: Blumin, 2006: 48.

Some of the scholars like Mendels (1972) were the strong supporters of the fact that the labor was ruralized, or let's say "proto-industrialized" at first, and later on, it was converted into an industrialized and urbanized actor with the beginning of machine industry. This view is backed 
up by Sir John Hicks' masterpiece named after A Theory of Economic History: "The Industrial Revolution is the Rise of Modern Industry, not the rise of industry as such." Maybe from here, it can be argued that labor became ruralized initially and then urbanized. To put in another way, "pre-industrial industry" is the first step of industrial and modern organization. The first phase of industrialization was shaped by traditional, rapid growth, market centered, and rural industry. Therefore, it is quite obvious that the urbanization of labor goes through its ruralization (Mendels, 1972: 241-261 and Hicks, 1969: 141).

\section{Labor Urbanization and Its Connotations in Turkey}

The urbanization of Turkish labor is identical with the trends in the world. Of course, timing is strikingly different as Turkish industrialization came into being virtually a century later than in the West, but the process is similar. In Turkey, labor has become urbanized with the emergence of industrial economy in coordination with the universal inclinations. Scholars have become distinct in their approaches to the formation of urban cities. As an instance, Ozer (2004) demonstrates the reasons for urbanization in Turkey in various factors such as demography (i), changes in the structure of the agriculture (ii), pulling forces (iii), intermediary factors (iv), law and policy oriented reasons (v), socio-psychological reasons (vi), and external factors (vii) while Keles (2010) categorizes the steps of Turkish urbanization with three components like pulling (a), pushing (b), and intermediary reasons (c) (Keles, 2010: 63-70 and Ozer, 2004: 49-60).

In the literature, there are a number of studies that focus on industrialization and urbanization in Turkey simultaneously. All these scholars are on the point of view that industrialization of the capital in 1950s and particularly free market economic model suggested and implemented by Adnan Menderes in Democrat Party, ruling party at that time, stemmed in the urbanization and industrialization of the labor in 1960s and 1970s. Five year development plans 
that commenced in 1963 paved the way for machinery industry and the concentration of the population as well. What's more, the political parties of Süleyman Demirel (Justice Party) and Turgut Özal (Motherland Party) fundamentally with their liberal economic model also played a leading role for the process. Hence, without industrial economy, it is of no avail for Turkish labor to be urbanized (for the connection between industrialization and urbanization in Turkey see also Oguz, 1995: 369-371; Kepir and Sinangil, 1994: 59-66; Celasun, 1994: 41-57; Habib, 1951: 4051; Berberoglu, 1980: 97-121; Ceyhun, 1988: 333-357; Kurucu and Chiristina, 2008: 289-297; Kaya, 2008: 161-181; Penninx, 1982: 781-818; Hale, 1980: 100-117; Kavzoglu, 2008: 429-438; Ocü, 1988: 38-64; Yentürk and Coban, 1992: 274-289).

\section{Turkey’s Journey towards Labor Unionism}

Trade unions were formed as economic inputs for labor markets since their ultimate goal is to defend the rights of the workers against employers and to enhance their wages. In a way, it can be stated that unionism emerged as a mandatory need and a reaction to the working conditions of Industrial Revolution (Caya, 2015: 559-568). That's why, trade unions are the equalizers of workplace and society (Western and Rosenfeld, 2011: 513-537). Moving from the definitions and theoretical backgrounds of trade unions, Turkish experience for unionism will be shared in terms of historical and legal framework in this part of the study. Indeed, there are plenty of definitions of trade unions, but I will mention some of them.

Unionism means labor movement and it is a sort of solidarity among those who share the same idea (Hemmerijckx, 2001: 124-125).

It is not easy to define the term of trade unions as it encompasses the freedom of association in terms of employees and employers, collective bargaining, strikes and lockout processes, and preservation of the mutual rights and interest (Budeli, 2012: 454). 
Trade unions are the democratic institutions of the labor markets, so the bigger and stronger unions are, the more powerful democracy will occur in a particular environment (Friedman, 2012: 18).

Turkish trade unionism is a discrete but a long journey and it is not entirely independent from the other countries due to the economic priorities and the policies that the country developed and implemented both in the Ottoman modernization and in the Republican period. Like the other industrialized countries, trade unionism in Turkey commenced to emerge in parallel to the reaction to industrialization process, which was quite slow compared to the industrialized countries since Turkey quitted agriculture and began industrialization later than the others. So as to bring on a holistic view concerning the formation of trade unions in Turkey, it is quite essential to have a look at both Pre-Republican and Post-Republican period as well. The Pre-republican period will be analyzed on five parameters such as Akhi Organization (i), Guilds (ii), Socialist Movements and Ottoman Empire (iii), Ottoman Labor Association (iv), and Ottoman Strike Law (v), whereas the characteristics of the formation of unionism during post-republican period is to be based on four eras: 1923-1947 (i), 1947-1963 (ii), 1963-1983 (iii), and 1983 and today (iv) (Tokol, 2014: 87-97).

\section{a) Pre-Republican Period}

1. Akhi Organizations: While focusing on pre-republican period on the basis of trade unionism, it is of great significance to glance at the Akhi organizations at first. Since $13^{\text {th }}$ century, Akhi organization or let's say Akhism, has been the reflection of futuwwa ${ }^{1}$ tradition that connotates generosity, charity, and goodness all over the course of Islam geography including Anatolia during Seljuks as well as Ottomans (Arnakis, 1953: 233, 234). Akhism, established by the craftsmen and merchants, is a multidimensional thought and its ultimate aim is to maximize the societal benefit

\footnotetext{
${ }^{1}$ Futuwwa is the "detailed description of the ritual, ceremonial behaviour, and customs observed in the mediaval Islamic guilds at various stages of promotion [...], giving an invaluable insight in the composition, structure, and social behaviour of a vital sector of Islamic urban society “ (Breebaart, 1972: 203), (for further information see also, Irwin, 2004: 161-170; Taeschner, 1953: 3-32; Gürsoy and Demirpolat, 2003: 203214; and Salinger, 1950. 481-493).
} 
of the society as a whole so as to settle social order. Mamuti (2013) gives the idea that Akhi organizations arrange commerce and so, they are like "chambers of commerce"; they try hard to resolve industrial problems between capital owners and the workers and they regulate labor relations so, they are just like "trade unions"; they prevent the creation of the monopoly, so they are "authority competitions"; they protect the consumers' rights by detecting the quality and the price of goods and services, so they resemble "service standard boards" (Mamuti, 2013: 241). All these explanations pave the way that Akhi organizations are the pioneer of trade unions in regards to their capability to solve industry or let's say commerce oriented predicaments, which is in line with the objective and the meaning of modern trade unions.

2. Islamic Guilds: Islamic guilds or in other words, Ottoman craft guilds, are the other contributory factors for the formation of trade unionism in Turkey. Of course, they do not take after the modern trade unions, yet still their functions and their back up to production, and their collaborative and vigilant comprehension to employee relations reveal the idea that they are something like the seeds of unionism in Turkey. And in the literature there are a great many studies that analyzes the correlation between guilds and trade unionism (see also Mastboom, 1994: 57-75; D’Arcy, 1971: 113-127; Kirkham, 1982: 1-10; Lucassen, De Moor and Van Zanden, 2008: 5-18; Tso, 1927: 16-29; Banks and Hesmondhalgh, 2016: 267-280).

Lewis (1937) states that craft guilds are the most fascinating institutions of Muslim civilization during medieval age. These are such an impressive organizations that they even leave an impact on the urban settlement, accordingly the cities are designed so as to meet the needs of guildsmen, which were the benchmarks of markets then (Lewis, 1937: 20).

Since classic era, craft guilds have been the crucial element of production in Ottoman state (Yildirim, 2002: 407). From their commencements in seventeenth century to their depletions in 
nineteenth century, Ottoman guilds were exposed to an evolution owing to several reasons: The first is the fact that Ottoman guilds had to develop some certain strategies for "inclusion" or "exclusion" in particular for the urban centers of Ottoman Empire because of Celali rebellions pushing effect to migration from rural areas. Secondly, the states approach to pious foundations altered in a radical way because of Empire's long lasting wars beginning in eighteenth century that constituted a heavy fiscal burden (Yildirim, 2008: 73). In the aftermath of Baltalimani Trade Agreement signed in 1838 that opens Ottoman markets to globe and that also capitalizes and liberalizes the guild-oriented economy, Ottoman guilds started to disappear. However, their roles on the production, their solidarities to protect their commercial rights, and their contributions to labor recruitment as well as labor relations as a whole make us contemplate on their vision for being a union like organizations.

3. Socialist Movements and Ottoman Empire: Ideologies are notable for the evolutionary change of a particular society as a whole for they foster the consciousness of the people while acting, behaving or even pondering in a certain way. The reason is that ideologies are something like an "institutionalization" for organizations including the states. Therborn (1980) argued that ideology ascertains people's way of life, their thinking style, and their manner of running and operating the world (Therborn, 1980: 2). Ideological figures which became quite dominant following western industrialization first, and later on, in cold war period in the aftermath of World War II, and this is the case for capitalist or socialist thought.

Socialism defined by Durkheim (1895-1896) as "above all a plan for the reconstruction of societies, a program for a collective life which does not exist as yet or in the way it is dreamed of, and is proposed to men as worthy of their preference. It is an ideal. It concerns itself much less 
with what is or was than what ought to be." (Durkheim, 1895-1896: 39, 40) has developed as an antithesis to capitalism.

There are also other statements of socialism as well. Professor T.N. Carver says "socialism is the public ownership and operation of all the means of production."; Bryan utters "socialism is the collective ownership, through the state, of all the means of production and distribution."; Professor Davis R. Dewey ascertains "it has never seemed to me possible to define the word so as to make it serviceable for general discussion. Socialism represents a movement. I do not see that it admits of sharper definition than Christianity, or barbarism, or culture ... The discussion has gone too far and the term is too widespread to bring down to any definition." (Martin, 1911: 347, $348)$.

As a matter of fact, thinking about the fact that socialism emerged as a sharp criticism towards capitalism, there are some other social protest movements against industrialization and the capitalistic values it suggested and which were developed by socialists scholars like Marxists and Utopians. Earlier socialists are historically communists and they have revolutionary ideas concerning the state, society, individuals, and the economy holistically. To illustrate, Marxists were on the idea that workers referred as 'proletariat' would carry out a revolution through which means of production would be replaced and a classless society would appear (Hechter, 1994: 156). Yüksel (2018: 385-414) as cited from Elliott (1992: 25-36) laid an emphasis on the Marxist thought about the reasons for the appearance of socialism:

Marx, in his works published later on under the name of Economic and Philosophical Manuscripts of 1844, was on the point of view that socialism came to fore as a perfect alternative to capitalism since the system was to be refreshed because capitalism was creating inequality in all the spheres of life. In order to change the system in a radical way and capture the attention of all, socialism had to give some options to individuals, working classes, labor 
unions, political parties, economic initiatives, in short to everyone in view of the fact that capitalism, by means of industrialization, granted a priceless gift for Western countries including Western Europa as well. The gift was industrialization, modernization, and democratization that presented capital accumulation, material wealth and technological improvement which were the inevitable parts of democratic, libertarian, and also egalitarian society. So, to compete with these notions of capitalism, socialism had to say different and alluring things to settle its system on working classes, labor unions, politics, co-operatives, governments, individual ownerships and etc.

Socialism is the direct and ultimate protest against capitalism indicated well before, and trade unions are the means toward socialist ideology assisted by Lenin through his words: "Trade unions are the school of socialism". Hence, socialist movements hit the Ottoman labor markets and therefore, several trade union-like associations and strikes ${ }^{2}$ were put into practice. Ottoman Labor Association (Osmanlı Amele Cemiyeti, 1894), Ottoman Strike Law (Tatil-i Esgal, 1908/1909) passed to interdict the strikes at the beginning of the twentieth century can be given as an example (Yüksel, 2017a: 122, 123). This can be interpreted in a way that the first trade union associations and the strikes bring the fore that socialism deeply left a great impact on the Ottoman modernization in $20^{\text {th }}$ century.

4. Ottoman Labor Association (Osmanlı Amele Cemiyeti): Ottoman Labor Association is the first trade union like organization established in 1894 illegally by Tophane-i Amire workers who had class consciousness (Toprak, 1993: 242). Before this association (1894), there is another worker organization called as "Labor Fraternity" established in 1871, the main aim of which is to proliferate the solidarity among workers. However, Labor Fraternity (1871) is something like the "follow up" of the Ottoman guilds; therefore, the first trade union like association equivalent to its western counterparts is the Ottoman Labor Association (Ekin, 1986: 39). The westernization 
initiatives, that is to say, modernization period commenced in the aftermath of Western take off in parallel to the industrial attack, the announcement of the Imperial Edict of Gülhane in 1839 and also the Edict of Reform in 1856, and the acknowledgement of Constitutional Monarchy in 1876 paved the way that there is not a way for Ottomans other than constitution, freedom, and individual rights. Taking into account in a cause and effect phenomena, these historical cornerstones led to the genesis of "organized labor".

5. Ottoman Strike Law (Tatil-i Esgal): Series of strikes in 1908 sparkled with the unionist slogans like "Liberte", "Egalite", and "Fraternite", which were, at the same time, the motto of French Revolution in 1789. The reason behind this was the atmosphere of relative "Freedom" set forward by the Committee of Union and Progress and the Committee had promised to unionists to assist their labor rights including unionism in return for the unionists support for the declaration of second constitutional period (Karakisla, 1992: 171).

1908 strike waves were not peculiar to Istanbul, in the stark contrast, it was prevalent to all regions of the Ottomans including İzmir, Thessaloniki, Damascus, and Beirut. However, it is to be noted that half of the strikes took place in the biggest three cites of Empire: Istanbul, Salonika, and Izmir. Unlike the studies of Akkaya (2010), according to the calculations of Karakisla (1992), there were around 111 registered strikes in 1908, and 39 of them were in Istanbul, 31 of them were in Salonika, and 13 of them were in İzmir, most majority of which related to the transportation sector. The costs of the strikes were gigantic as they happened in the outstanding sectors of the state. Nevertheless, due to the organizational deficiency, financial problems of the workers during strikes, companies' employment of the new workers in the place of strikers, and the unwilling approach of both Ottoman government and the Committee members, 1908 strikes did not last long 
except from a few of them exceeding one week (Karakisla, 1992: 175, 176) . Accordingly, Ottoman Strike Law passed in 1908 as a kind of enactment and then its journey towards being a law in 27 July 1909 was activated, and all the strikes, fundamentally in state-oriented jobs were forbidden (Güney and Aslanova, 2014: 261; Okcün, 1982: 1).

\section{b) Post Republican Period}

As demonstrated well beforehand, the characteristics of the formation of unionism during post-republican period is to be based on four eras: 1923-1947 (i), 1947-1963 (ii), 1963-1983 (iii), and (1983 and still). Just as making such a categorization like this, Turkey's economic and political enterprises played a very common ground for the rehabilitation of the employee rights including unionism, collective bargaining, and the strikes. Consequently, those years between1923-1947 reflected the period on which national capital accumulation attempts were on the rise through economic liberalism first, and then the activation of Keynesian economic policies in pursuit of Great Depression. 1947-1963 was the era referred as the initial phase of golden age of labor relations as well as urbanization of capital in Turkey. As for the third sphere of unionism, it began with the enactment of second trade union law (No: 274/275) in 1963 and this contained virtually twenty years of time span between 1963-1983, so this stage was called as the second phase of golden age in labor relations and the urbanization of labor. The developments from 1983, when neoliberal flows started to blow in parallel to the globalization period, up till today were the years of neoliberalism as well as insecure work (Mahirogullari, 2001: 161-190; Ekin, 1986: 33-51 and Wannöffel, 2011: 545-569).

1. 1923-1947 (Attempts for Accumulation of National Capital): Other than some sorts of decisions for the modern labor in Izmir Economic Congress in 1923 and the enactment of first 
labor law (No: 3006) in 1936, we do not see any labor attack in this period fundamentally on the idea of labor organizations. In particular, this period focused on the national capital accumulation on account of the fact that Ataturk, the leader of modern Turkish Republic, was on the idea that Turkey could not have been an independent state unless economic freedom had been activated. Therefore, economic liberalism was adapted in line with the world conjuncture from 1923 to 1929. But, the Great Depression, that is to say, "Black Thursday" in 1929, altered Turkish economic policies from liberalism to Keynesian economy, and the state intervention to economy came to fore. Public economic enterprises were the best instances of this initiative as the establishment of market economy, at that time, was unfeasible due to the lack of capital accumulation. So as to expatiate an academic standpoint, it can be argued that the keywords of this era are Izmir Economic Congress (1936), Liberal Market Policies at first, Great Depression (1929), Keynesian Economic Policies as a second, Public Economic Enterprises, First Labor Law (No: 3006) in 1936 (Makal, 2004: 125-129).

\section{1947-1963 (First Phase of Golden Age of Labor Relations and Urbanization of Capital):}

1947-1963 was the period on which legal seeds of unionism started due to the fact that one party hegemony gradually vanished with the foundation of Democrat Party in January $7^{\text {th }}$, in 1946 and Keynesian economic policies came to fore as a reaction to the catastrophe of Great Depression. Thus, the phase of 1947-1963 is referred as the first and foremost Golden Age of Labor Relations and Urbanization of Capital in parallel to the state intervention to the markets. In 1947, Trade Union and Trade Union Association Law (No: 6542) was passed and establishment of the trade unions in private sector was legalized but strikes were still prohibited. What's more, the foundation of the Confederation of Turkish Trade Unions in 1952 (TURK-IS) and the inauguration of Turkish 
Confederation of Employer Associations in 1962 (TISK) presented Turkish labor markets a ‘confederative' structuring. Last but not least, acknowledgement of 1961 Constitution (Article 47) gave the first strike right to the private sector employees. Therefore, the main keywords of this era are the First Trade Union Law in 1947 (No: 6542), multiparty political system, Confederation of Turkish Trade Unions (1952), Turkish Confederation of Employer Associations (1962), and following 1960 military coup, 1961 Constitution amendments through which first strike right for business workers was given (Wannöffel, 2011: 548 and Kocak, 2008: 77-83).

\subsection{3-1983 (Second Phase of Golden Age of Labor Relations and Urbanization of Labor):}

This period is of great significance for depicting the second timeline of the golden age of labor relations and in this era, rural workers initiated to migrate from the rural areas to the urban settings and then this is the period of 'labor urbanization'. Resettlements concerning labor relations still kept on between 1963-1983 with the enactment of Second Trade Union and Collective Bargaining Law in 1963 (No: 274/275) and the Second Labor Law in 1967 (No: 931). Second Trade Union and Collective Bargaining Law enacted in 1967 is structurally different from the prior ones. Unlike from the prior one, Second Trade Union and Collective Bargaining Law was passed in two discrete documents, that is to say, Trade Union Law and Collective Bargaining Law are separate. As for the Second Labor Law, it can be referenced that it is the shortest labor law of post-republican period. Apart from individual and collective labor laws, there are some other developments like the establishment of Confederation of Progressive Trade Unions of Turkey in 1967 (DISK), Confederation of Nationalist Trade Unions in 1970 (MISK), and also Confederation of HAK-IS Trade Unions in 1976 (HAK-IS) (Millen, 1969: 31-35). 
4. 1983 and Today (Neoliberal Flows and the Problems of Insecure Work): The last stage concerning trade unionism in Turkey is the appearance of neoliberalism following Oil Crisis in 1973. As a matter of fact, neoliberalism in Turkey, as the reorganization of the labor markets based upon 'free enterprises', arose subsequently January 24 Decisions in 1980. These decisions are the formal means to legalize neoliberalism in all the compartments of the economy. With neoliberalism taking its strength from the globalization process, state intervention to economy has become marginalized and the private initiative has become dominant. In order to be in rivalry with their universal equivalents, Turkish private capital owners have weakened the working class in terms of wages and the labor rights. So, this era starting from 1983 and to today is defined as the one on which neoliberal flows and the problems of insecure work have been prevailing, which is also sustained by the deregulation (labor market flexibility), decentralization (losing the centralized facet of collective bargaining), and de-unionization (reduction in the number of trade unions and their members) process (Yüksel, 2017b: 255-268). In spite of these drawbacks, there are some other reforms concerning trade union or labor laws. As an example, the enactment of Third Trade Union and Collective Bargaining Law in 1983 (No: 2821/2822), Constitutional Amendments in 1992 that gave government employees to be unionized in theory, but it was not activated till 2001 with the enactment of Government Employees Trade Unions and Collective Contract Law (No: 4688), Fourth Labor Law in 2003 (No: 4857), and the September 12 Referendum in 2010 that legalized the collective bargaining of public workers with the state. September 12 Referendum did not legitimize the right to strike for government employees. All these things pave the way that the keywords of this era are the January 24 Decisions (1983), Globalization, Neoliberalism, Deregulation, Deunionization, Decentralization, Third Trade Union and Collective Bargaining Law (1983), 1992 Constitutional Regulation, Law of Trade Union and 
Collective Bargaining for Public Workers (2001), Fourth Labor Law (2003), and September 12, Referendum in 2010 (Kocer, 2007: 249-252).

\section{Research Methodology}

Discourse analysis is used as the method of the research. Discourse analysis, as a method used frequently in qualitative studies, is defined by Macdonald (2003) as a "system of communicative practices that are integrally related to wider social and cultural practices, and that help to construct specific frameworks of thinking” (Macdonald, 2003). In a way, discourse analysis is something like predicting who is behind the curtains or let's say reading between the lines. This sort of method is utilized in this study so as to pick up trade union, urbanization, and labor market oriented issues in the movie as in line with the statement of the Mithun (2018) and he utters that "all discourse analysis work shares a focus on extended bodies of speech in its communicative context. [...] Grammar provides speaker with tools for packaging information. And how information is packaged depends on the larger discourse context, the flow of thought through time, the communicative and social goals of the speaker, the presumed knowledge state of the audience, and more." (Mithun, 2018: 12).

Figure 1. In Blood Money (Diyet), Hacer's Luddite Initiative to Break up the Factory's Monster Machine which Causes Hasan, Her Husband, to Lose His Arm

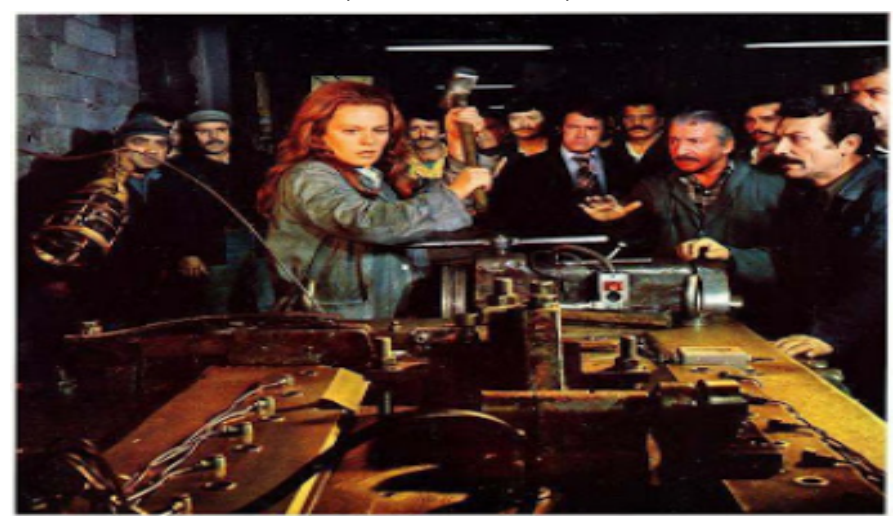

Source:https://www.youtube.com (Accessed June 3, 2020) 


\section{Case Background: The Film Blood Money (Diyet)}

Blood Money (Diyet) constitutes our study's case background. It was filmed in 1975. The film is closely related to the urbanization of the labor and their struggle for unionism. The first scene of the movie is the machines in the factory which displays the reality that it mainly focuses on labor markets and the dependent workers. So, it is a labor film that depicts the atmosphere of the urban labor markets in 1970s in Turkey. The main problem of the film is the exploitation or let's says the removal of the labor by the employees. There are work assassinations in the plant due to antiquated machines and some of the employees are disabled, yet still the employer called as Mr. Salim (Salim Bey) shuffles to change the machine and to reorganize the factory in a modern way. Mr. Salim's main concern is, of course, to lose money. Therefore, the factory workers decide to unionize but Mr. Salim does his best to disrupt the process. He even deceives the government officials by paying bribes to them. However, at the end of the film, it is seen that the great majority of the workers are unionized, but this delayed attempt of the workers does not impede another work accident, the accident that Hasan loses his arm. To the perspective of the film and the statement of Hacer, the wife of Hasan, like "It's our fault", it can be clearly argued that the movie was shot to assist unionization in Turkish labor markets.

Figure 2. Shanty Houses in Istanbul Constructed by Earlier Immigrant Labors in Blood Money (Diyet)

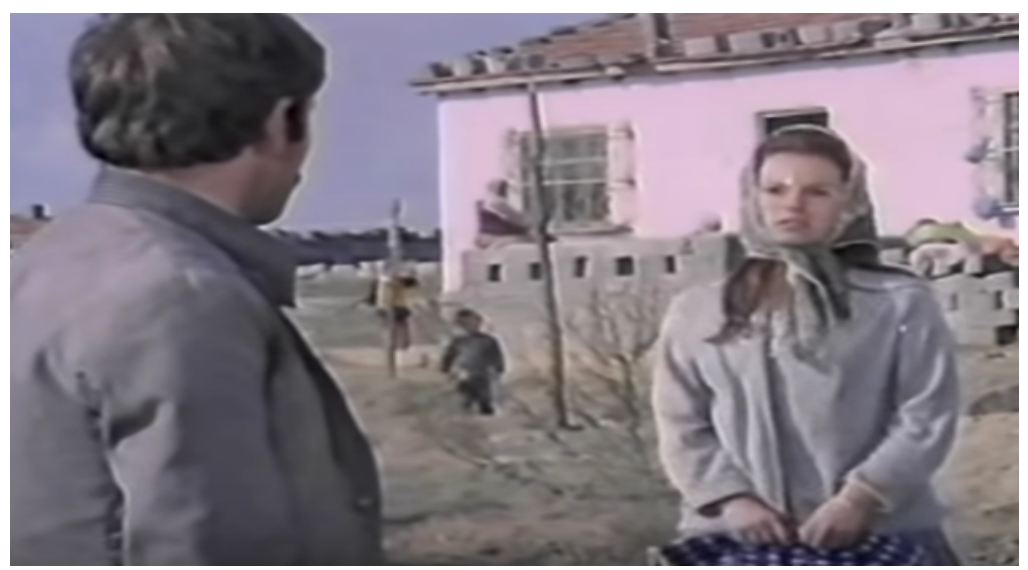




\section{Casting}

The main actors of the movie "Blood Money (Diyet)" is Hakan Balamir (as Hasan), Hülya Koçyiğit (as Hacer), Erol Taş (as Bilal Usta), Erol Günaydin (as Mevlüt), Günay Güner (as Mustafa), and Yaşar Şener (as Muhsin), and Güner Sümer (as Salim), Atuf Kaplan (as the father of Salim) (URL 1 2018). The movie was shot from a socialist perspective in 1974 and in terms of industrial relations, it portrays the situation of the Turkish labor markets in 1970s. So, a great many of the actors like Hasan, Hacer, Bilal Usta, Mevlüt, Mustafa, and Muhsin are factory workers while Salim and his father are the employers, which can be interpreted in a way that employee and employer relationships are the main agenda of the movie. The movie suggests that employees are "disadvantageous" while that is not the case for employers.

\section{Data Collection and Analysis}

This study is built upon a qualitative discourse analysis. The data was analyzed by MAXQDA 2018 program which is commonly used for content and discourse analysis as a visual and technical tool as well. The interface of MAXQDA software takes after to the WINDOWS and basically it has four windows such as "document system”, “system code”, “document browser”, and "retrieved segments". Document system provides the data from textual and pictorial items or video assisted sources. System code enables the researcher to write codes and sub codes depending upon the way that the document is wished to be analyzed. Document browser is utilized to edit and consult the text while retrieved segment is the tool for checking the coded material (Oliveira et al., 2015: 76). 
Figure 3. Code Matrix Browser Analysis of the Codes (Using MAXQDA)

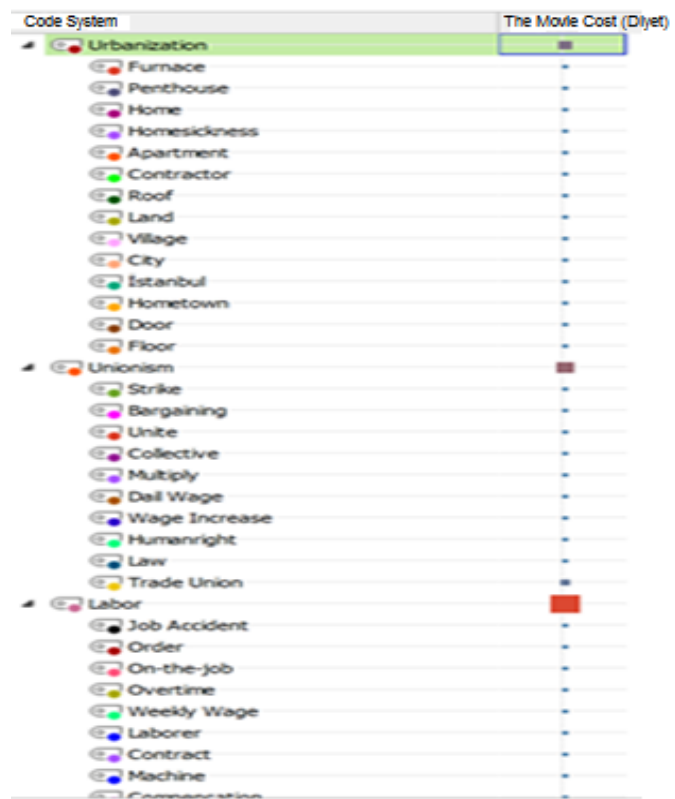

The film script was put into analysis depending upon three main codes written such as "urbanization", "unionism", and "labor" which is also in coordination with the theoretical aspect of the study. In addition, 14 sub codes for "urbanization" (e.g. penthouse, land, apartment, contractor, Istanbul, floor, village, city, furnace, homesickness, roof, door, hometown, and home), $10 \mathrm{sub}$ codes for "unionism" (e.g. strike, multiply, wage increase, bargaining, unite, humanright, collective, daily wage, law, and trade union), and 17 sub codes for "labor" (e.g. laborer, contract, weekly wage, farm laborer, order, employee, bread, overtime, compensation, on-the-job, job accident, factory, money, Turkish lira, machine, work, and master) were written. In total, 246 codes were formed all through the text. For these categories, 48 codes for "urbanization", 73 codes for "unionism", and 125 codes for "labor" were determined accordingly. ${ }^{3}$ These codes were written depending upon the thematic overview of the study. The codes were generally assigned to the words, phrases, sentences or paragraphs that overlap with the contextual meaning of the main codes (Figure 3). 

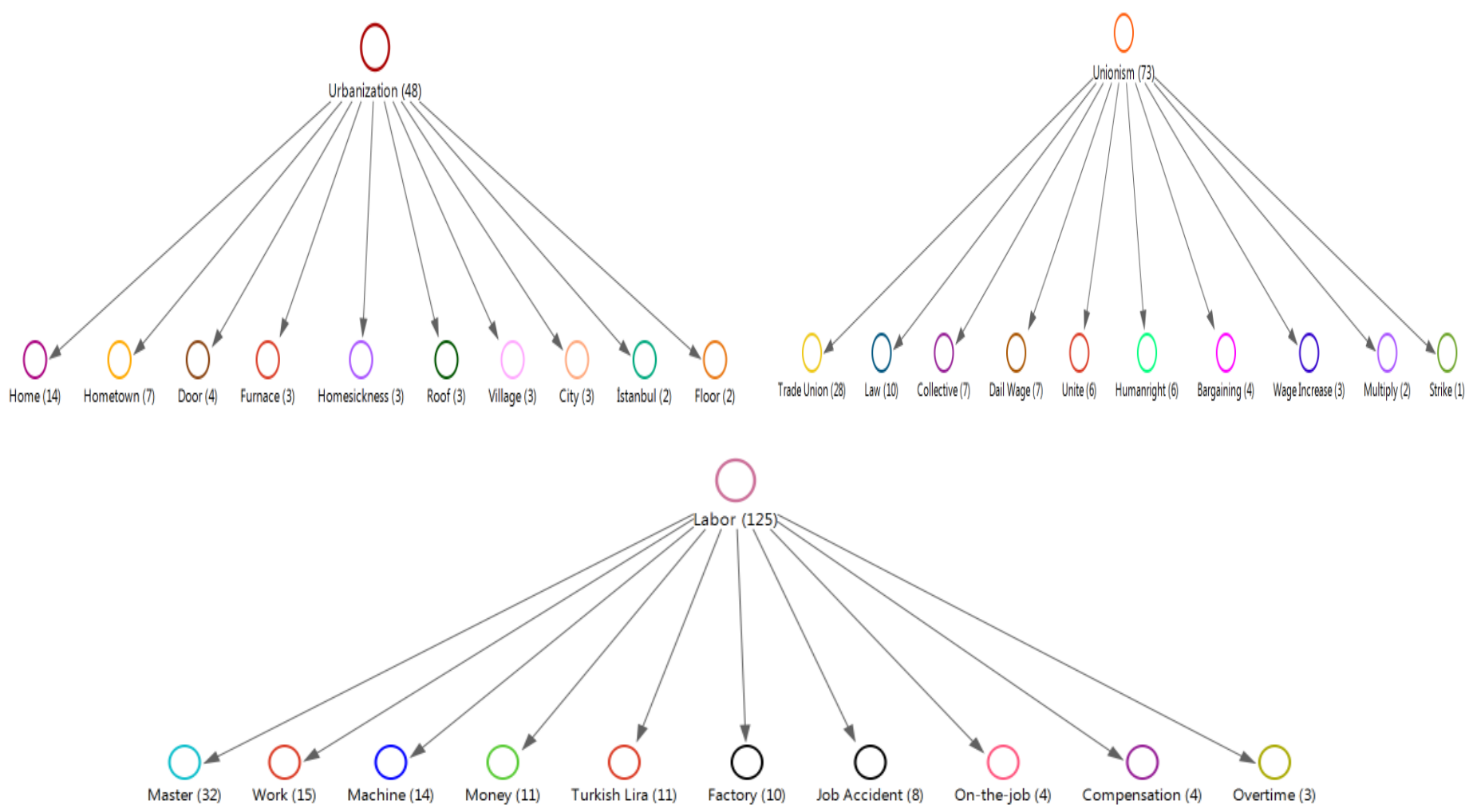

According to the hierarchical code sub code model for "urbanization", "unionism", and "labor" (using MAXQDA), it is illustrated that 48 sub codes for "urbanization", 73 sub codes for "unionism", and 125 sub codes for "labor" were determined. Most of the sub codes belong to the main code of "labor" $(n=125)$. As for second, "unionism" comes to prominence $(n=73)$ and at last "urbanization" ( $\mathrm{n}=48)$ is on the ground. This weighting also functions to the particular issues that the film deals with. Then, this means that the main issue of the film is the unionization problem of the Turkish labor markets in parallel to the urbanization process in the aftermath of 1963 when the labor migration from rural areas to the urban settings acutely commenced. As soon as the labor migrants stepped in the cities, they were quite vulnerable and open to exploitation due to their 
illiteracies. The landowners of agrarian society are the factory owners in urban districts and they dominate the production, so they manipulate the labor and the capital, which is the case for its Turkish equivalents (Figure 4).

\section{Findings}

The thematic content as well as the discourse analysis of the movie Blood Money (Diyet) was carried out through document portrait analysis in MAXQDA. Through the document portrait analysis, one can comprehend the main context of the study. Here, the main colors like pink $\left({ }^{\bullet}\right)$,

orange ( ), and deep red ( ) symbolizes that the movie is basically grounded on three themes like

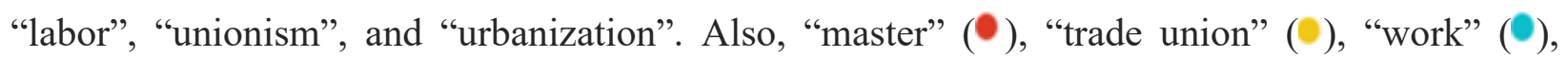
"factory" $(\bullet)$, "machine" $(\bullet)$ are the other colors to portray the general framework of the text. Within this framework, Figure 5 demonstrates that the film was made to give particular messages to labor markets in regards to employees' assistance to be unionized which became mandatory because of bad working conditions in urban areas and the hegemonic role of the employer who hesitated to take initiatives to reform in the factory (Figure 5). 
Figure 5. Document Portrait of the Movie Blood Money (Diyet) (Using MAXQDA)

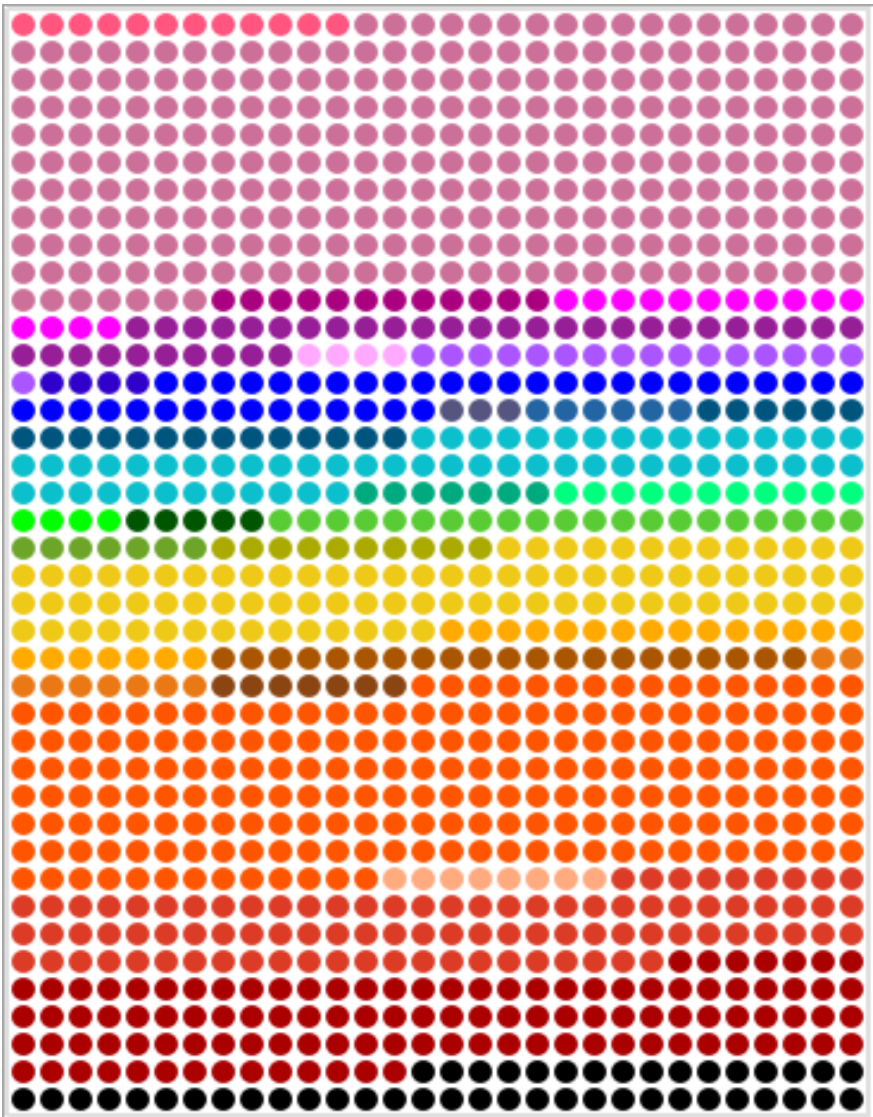

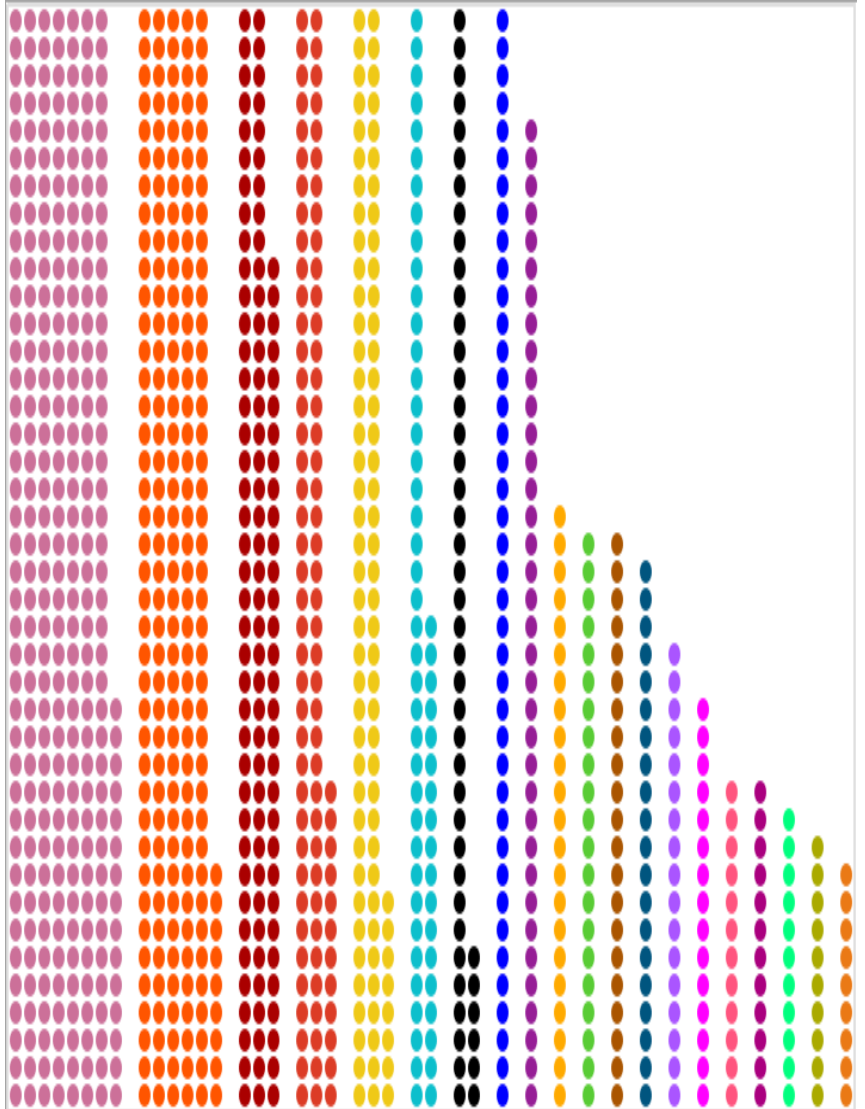

Looking at the frequency of the core codes for "urbanization", it can be referenced that there are actually 14 sub codes (e.g penthouse, land, apartment, contractor, Istanbul, floor, village, city, furnace, homesickness, roof, door, hometown, and home) and 48 categories for the "urbanization" itself. The frequency of the sub codes are distributed $n=1(2,08 \%)$ for "penthouse", $n=1(2,08 \%)$ for "land”, $n=1$ (2,08\%) for “apartment”, $n=1$ (2,08\%) for “contractor”, $n=2$ (4,17\%) for "Istanbul”, $n=2(4,17 \%)$ for "floor”, $n=3(6,25 \%)$ for “village”, $n=3(6,25 \%)$ for “city”, $n=3(6,25 \%)$ for "furnace”, $n=3$ (6,25\%) for “homesickness", $n=3$ (6,25\%) for "roof”, $n=4$ (8,33\%) for "door", $n=7$ $(14,58 \%)$ for "hometown", and $n=14(29,17 \%)$ for "home". Under "urbanization" main code, the most commonly used sub codes is "home" while the least ones are the "penthouse", "land", 
"apartment", and "contractor". These percentages unveil the fact that "home" is the sinequanon to symbolize the urbanization process in the film (Table 2).

Table 2. Frequency of Sub codes for "Urbanization" (Using MAXQDA)

\begin{tabular}{lll}
\hline Sub codes of Urbanization & Categories/Codes (n) & Frequency (\%) \\
\hline Penthouse & 1 & 2,08 \\
Land & 1 & 2,08 \\
Apartment & 1 & 2,08 \\
Contractor & 1 & 2,08 \\
Istanbul & 2 & 4,17 \\
Floor & 2 & 4,17 \\
Village & 3 & 6,25 \\
City & 3 & 6,25 \\
Furnace & 3 & 6,25 \\
Homesickness & 3 & 6,25 \\
Roof & 3 & 6,25 \\
Door & 4 & 8,33 \\
Hometown & 7 & 14,58 \\
Home & 14 & 29,17 \\
\hline TOTAL & $\mathbf{4 8}$ & $\mathbf{1 0 0 , 0 0}$ \\
\hline
\end{tabular}

As for the frequency of the core codes for "unionism", it can be revealed that there are actually 14 sub codes (e.g. strike, multiply, wage increase, bargaining, unite, human right, collective, daily wage, law, and trade union), and also 74 categories for the "unionism" itself. The frequency of the sub codes are distributed $n=1$ (1,35\%) for "strike”, $n=2$ (2,70\%) for "multiply", $n=3(4,05 \%)$ for "wage increase", $n=4(5,41 \%)$ for "bargaining”, $n=6(8,11 \%)$ for "unite”, $n=6$ $(8,11 \%)$ for "human right", $n=7(9,46 \%)$ for “collective”, $n=7(9,46 \%)$ for "daily wage”, $n=10$ (13,51\%) for "law", and $n=28$ (37,84\%) for "trade union". Under "unionism" main code, the most commonly used sub codes is "trade union" while the least one is the "strike". These proportions pave the way that the film is fundamentally formed on the basis of "trade union" issue, 
which is one of the most problematic areas of Turkish labor markets in 1970s when neoliberal breezes flew slowly and the hegemonic power of employer became relatively authoritative (Table 3).

Table 3. Frequency of Sub codes for "Unionism” (Using MAXQDA)

\begin{tabular}{lll}
\hline Sub codes of Unionism & Categories/Codes (n) & Frequency (\%) \\
\hline Strike & 1 & 1,35 \\
Multiply & 2 & 2,70 \\
Wage Increase & 3 & 4,05 \\
Bargaining & 4 & 5,41 \\
Unite & 6 & 8,11 \\
Human right & 6 & 8,11 \\
Collective & 7 & 9,46 \\
Daily Wage & 7 & 9,46 \\
Law & 10 & 13,51 \\
Trade Union & 28 & 37,84 \\
\hline TOTAL & $\mathbf{7 4}$ & $\mathbf{1 0 0 , 0 0}$ \\
\hline
\end{tabular}

Concerning the frequency of the core codes for "labor", it can be referenced that there are 17 sub codes (e.g. laborer, contract, weekly wage, farm laborer, order, employee, bread, overtime, compensation, on-the-job, job accident, factory, money, Turkish lira, machine, work, and master), and also 125 categories for the "labor" itself. The frequency of the sub codes are distributed $n=1$ $(0,80 \%)$ for "laborer", $n=1(0,80 \%)$ for "contract”, $n=1(0,80 \%)$ for "weekly wage”, $n=2$ (1,60\%) for “farm laborer”, $n=2$ (1,60\%) for “order”, $n=3(2,40 \%)$ for “employee”, $n=3(2,40 \%)$ for "bread", $n=3$ (2,40\%) for "overtime", $n=4$ (3,20\%) for "compensation", $n=4(3,20 \%)$ for "on-the-job", $n=8(6,40 \%)$ for "job accident", $n=10$ (8,00\%) for "factory", $n=11(8,80 \%)$ for “money”, $n=11$ (8,80\%) for “Turkish lira”, $n=14$ (11,20\%) for "machine”, $n=15(12,00 \%)$ for “work", and $n=32(25,604 \%)$ for "master". Under "labor" main code, the most widely utilized sub code is "master" while the least ones are the "laborer", "contract", and "weekly wage". 
These frequencies bring out in a holistic way that labor relations, and its components such as "master", "work", "machine", "factory", and so on are the basic issues conversed about through the film. The film attempts to unionize the labor by means of crashing and questioning the ultimate role of employer. The intensity of the categories in the "labor" which is the highest among the others, in addition, assists the genuineness that the labor is the 'core' of the text (Table 4).

Table 4. Frequency of Sub codes for "Labor" (Using MAXQDA)

\begin{tabular}{lll}
\hline Sub codes of Labor & Categories/Codes $(\mathbf{n})$ & Frequency $\mathbf{( \% )}$ \\
\hline Laborer & 1 & 0,80 \\
Contract & 1 & 0,80 \\
Weekly Wage & 1 & 0,80 \\
Farm Labourer & 2 & 1,60 \\
Order & 2 & 1,60 \\
Employee & 3 & 2,40 \\
Bread & 3 & 2,40 \\
Overtime & 3 & 2,40 \\
Compensation & 4 & 3,20 \\
On-the-job & 4 & 3,20 \\
Job Accident & 8 & 6,40 \\
Factory & 10 & 8,00 \\
Money & 11 & 8,80 \\
Turkish Lira & 11 & 8,80 \\
Machine & 14 & 11,20 \\
Work & 15 & 12,00 \\
Master & 32 & 25,60 \\
\hline TOTAL & $\mathbf{1 2 5}$ & $\mathbf{1 0 0 , 0 0}$ \\
\hline
\end{tabular}

Depending upon the discourse analysis for the film script, it can be viewed that "urbanization" main code is closely connected with other sub codes. As stated beforehand, these are "penthouse (1 code)", "land (1 code)", “apartment (1 code)", “contractor (1 code)”, "Istanbul (2 codes)", "floor (2 codes)”, "village (3 codes)”, “city (3 codes)", "furnace (3 codes)”, "homesickness (3 codes)”, 
"roof (3 codes)", “door (4 codes)", "hometown (7 codes)", and "home (14 codes)”. As witnessed from Figure 6 named after code sub code categories model for "urbanization", it is quite clear that the sub code frequently coded under the main code "urbanization" is the code of "home", which directly indicates the fact that "urbanization is home", or let's say "it is the collection of homes". In other words, "urbanization is rebuilding new houses for new residents coming from rural areas of the city". To put in another way, Figure 6 covers a strong relationship between the main code of "urbanization" and sub code "home" (Figure 6).

Figure 6. Code Sub Code Categories Model for "Urbanization" (Using MAXQDA)

According to

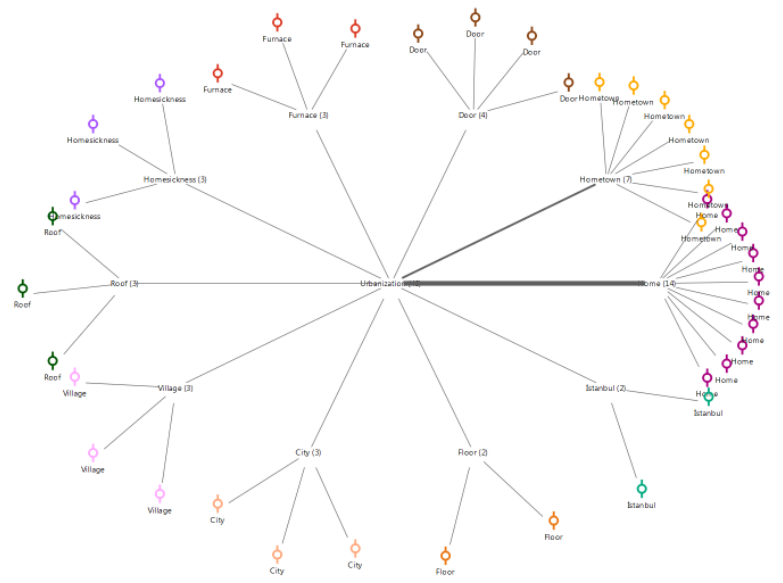

Figure 7 called as

code sub code categories model for

"Unionism", it can be demonstrated that "unionism" main code is in close relationship with the other sub codes like "strike (1 code)", "multiply (2 codes)", "wage increase (3 codes)", “bargaining (4 codes)”, “unite (6 codes)”, “humanright (6 codes)”, “collective (7 codes)”, “daily wage (7 codes)", "law (10 codes)", and "trade union (28 codes)". In this figure, sub code commonly coded under the main code "unionism" is the code of "trade union", which gives the message that "unionism implies trade unions by multiplying the strength of employees through collective action and via the implementation of the union and the labor laws". Figure 7 gives these hints by verifying intense correlation between unionism and trade union as well: "trade unions are legal for human right", "trade unions are the apparatuses for collective action in order to render 
the disadvantages employees to advantaged masses within the presence of capital owners" (Figure 7).

Figure 7. Code Sub Code Categories Model for "Unionism” (Using MAXQDA)

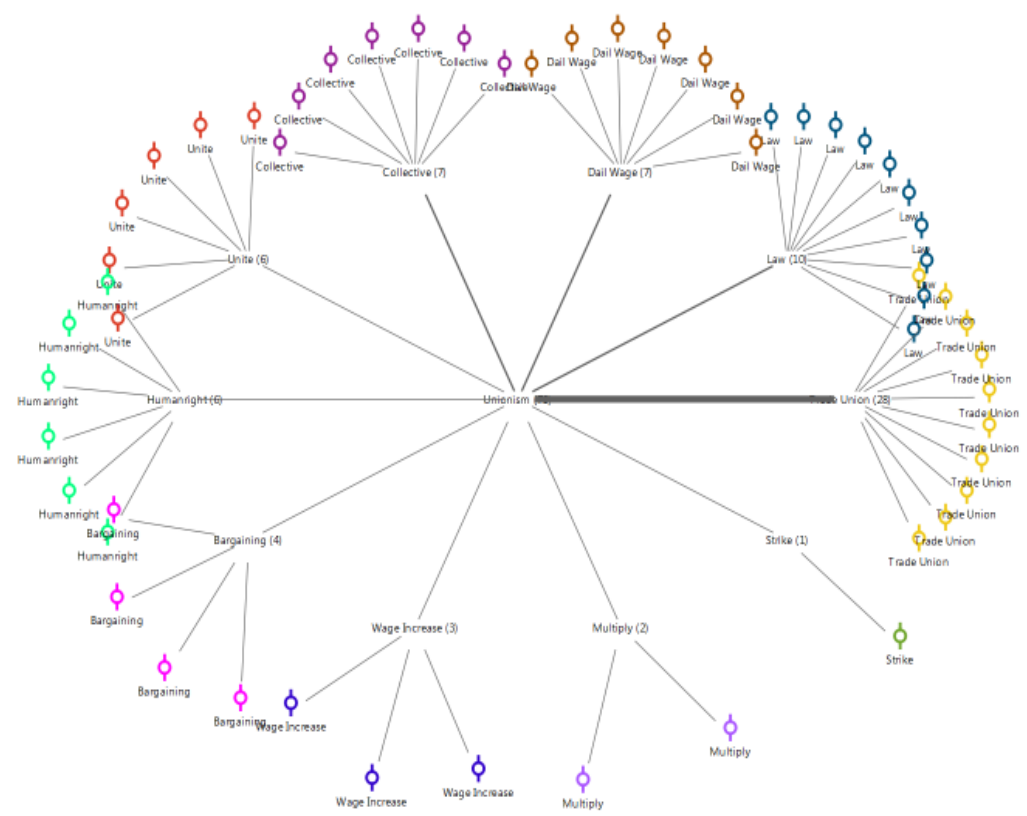

Moving from Figure 8 called as code sub code categories model for "labor", it can be debated that "labor" main code is in close relationship with the other sub codes such as "laborer (1 code)", “contract (1 code)", "weekly wage (1 code)", "farm laborer (2 codes)", "order (2 codes)", “employee (3 codes)", "bread (3 codes)", “overtime (3 codes)”, “compensation (4 codes)", “on-the-job (4 codes)”, “job accident (8 codes)”, "factory (10 codes)”, "money (11 codes)", "Turkish lira (11 codes)", "machine (14 codes)", "work (15 codes)", and "master (32 codes)" (Figure 8).

Figure 8. Code Sub Code Categories Model for "Labor" (Using MAXQDA) 


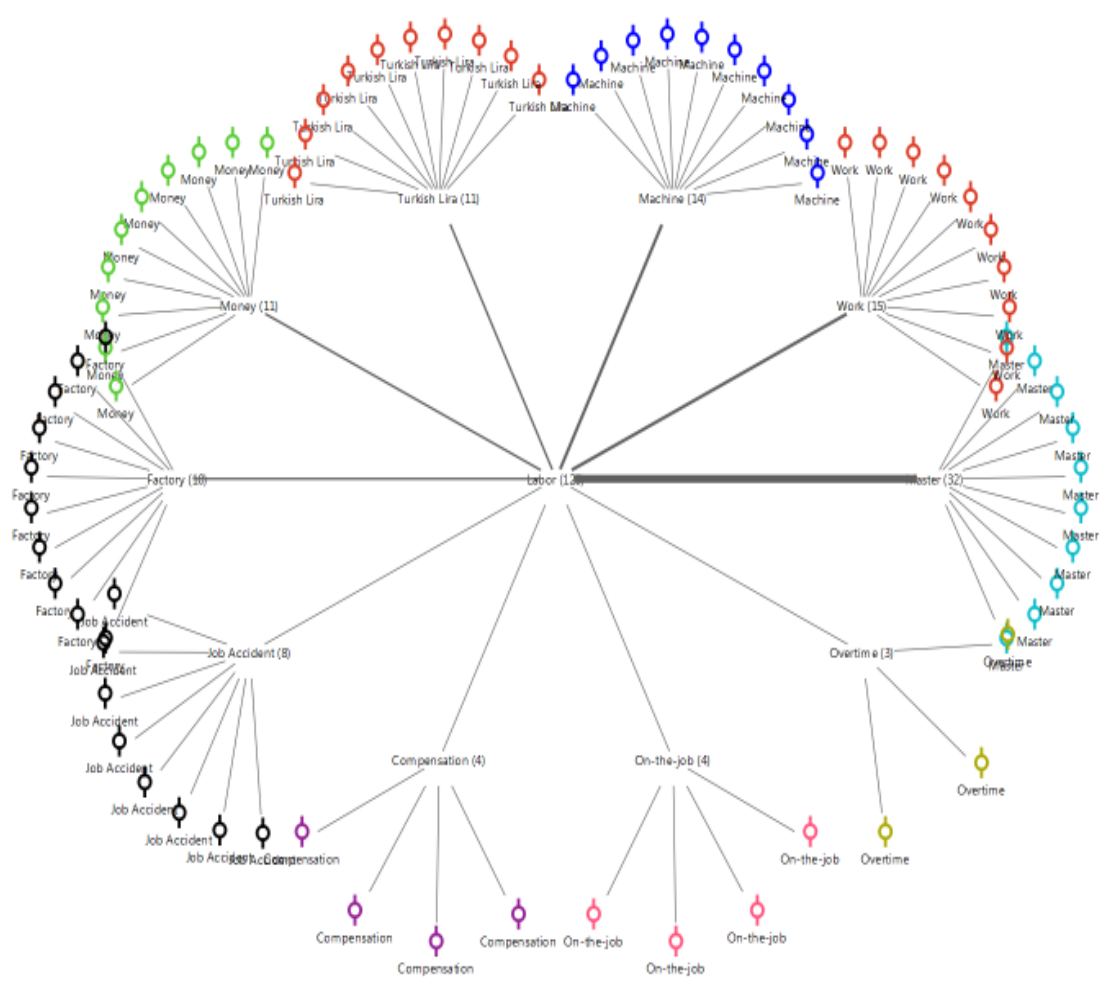

In figure 8, sub codes commonly coded under the main code "labor" are the codes of "master", "work", and "machine" in a consecutive way which gives the message that "labor markets are characterized by labor, work, and machines". Figure 8 gives these hints by verifying intense correlation between labor and master as well: "industrialization prepares the ground for machine/factory oriented production and a new class of work called as employee" and "industrialization forms particular places for mass production where work life balance is problematic due to the employees' overtime work sustained by employers pressure for high profits", "The only protective shield for these socially, economically, and politically excluded group is the union that is a collective voice for all of them" (Figure 8).

Table 5. The Most Commonly Used 20 Words in the Film Script (Using MAXQDA)

\begin{tabular}{llll}
\hline Word & Word Length & Frequency (n) & \% \\
\hline Usta (Master) & 4 & 192 & 3,58 \\
Hasan (Employee) & 5 & 122 & 2,28 \\
Bilal(Master of Employees) & 5 & 109 & 2,03 \\
\hline
\end{tabular}




\begin{tabular}{|c|c|c|c|}
\hline Hacer (Employee) & 5 & 99 & 1,85 \\
\hline Salim (Employer) & 5 & 73 & 1,36 \\
\hline $\begin{array}{l}\text { Mevlüt(Employee, Member of } \\
\text { Trade Union) }\end{array}$ & 6 & 51 & 0,95 \\
\hline Bey (Mr.) & 3 & 46 & 0,86 \\
\hline $\begin{array}{l}\text { Muhsin (Representative of Trade } \\
\text { Union) }\end{array}$ & 6 & 36 & 0,67 \\
\hline Hacer'in (Hacer's, Employee) & 8 & 32 & 0,60 \\
\hline Yunus (Hacer's Father) & 5 & 32 & 0,60 \\
\hline Mustafa (Disabled Employee) & 7 & 31 & 0,58 \\
\hline Var (available) & 3 & 31 & 0,58 \\
\hline Mustafa'nın (Mustafa's) & 11 & 30 & 0,56 \\
\hline Babası (Father) & 6 & 29 & 0,54 \\
\hline Iş (Work) & 2 & 29 & 0,54 \\
\hline Yok (Unavailable) & 3 & 29 & 0,54 \\
\hline Zehra (Mustafa's Mother) & 5 & 25 & 0,47 \\
\hline Gibi (Like) & 4 & 24 & 0,45 \\
\hline Bi (A) & 2 & 23 & 0,43 \\
\hline На (Huh) & 2 & 23 & 0,43 \\
\hline
\end{tabular}

The most commonly used 20 words in the film script is distributed 3,58\% $(n=192)$ for "Usta (master)"; 2,28\% (n=122) for "Hasan (Proper Noun, Employee)"; 2,03\% (n=109) for "Bilal (Proper Noun, Master of Employees)"; 1,85\% (n=99) for "Hacer (Proper Noun, Employee)"; 1,36\% (n=73) "Salim (Proper Noun, Employer)"; 0,95\% $(\mathrm{n}=51)$ for "Mevlüt (Proper Noun, Employee, Member of Trade Union)"; 0,86\% (n=46) for "Bey (Mr.)"; 0,67\% (n=36) for "Muhsin (Proper Noun, Representative of Trade Union)"; 0,60\% (n=32) for "Hacer'in (Hacer's, Employee)"; 0,60\% (n=32) for "Yunus (Proper Noun, Hacer's Father)"; 0,58\% (n=31) for "Mustafa (Proper Noun, Disabled Employee)"; 0,58\% (n=31) for "Var (available)"; 0,56\% (n=30) for "Mustafa'nın (Mustafa's)"; 0,54\% (n=29) for "Babası (Father)"; 0,54\% (n=29) for "Iş 
(Work)"; 0,54\% (n=29) for "Yok (Unavailable)"; 0,47\% (n=25) for "Zehra (Proper Noun, Mustafa's Mother)"; 0,45\% (n=24) for "Gibi (Like)"; 0,43\% (n=23) for "Bi (A)"; and 0,43\% $(\mathrm{n}=23)$ for "Ha (Huh)" (Table 5). In the text, the most frequently used word is "master" which is in line with Table 4 (Frequency of Sub codes for "Labor") and Figure 8 (Code Sub Code Categories Model for "Labor”) (Table 5).

\section{Concluding Remarks}

Based on a particular Turkish labor/unionism themed film called as Blood Money (Diyet), this essay has examined the urbanization of Turkish labor and their struggle to find a way for unionization. Discourse analysis as a sort of qualitative study was used as a method of the research. In the research, the film script of the film named after well beforehand was analyzed through MAXQDA 2018 qualitative analysis program. This program has enabled us to create some certain codes and sub codes. Three main codes like "urbanization", "unionism", and "labor" which is also in coordination with the theoretical aspect of the study was composed in the aftermath of detailed analysis of the film script. In addition, 14 sub codes for "urbanization" (e.g. penthouse, land, apartment, contractor, Istanbul, floor, village, city, furnace, homesickness, roof, door, hometown, and home), 10 sub codes for "unionism" (e.g. strike, multiply, wage increase, bargaining, unite, human right, collective, daily wage, law, and trade union), and 17 sub codes for "labor" (e.g. laborer, contract, weekly wage, farm laborer, order, employee, bread, overtime, compensation, on-the-job, job accident, factory, money, Turkish lira, machine, work, and master) were formed.

The unionization of Turkish labor is tough and a fluctuating process because of political interventions and economic handicaps. So, Turkish trade unionism is not extremely independent from political initiatives as well as economic drawbacks. Political attempts are OK for the 
formation of trade unions not only in Turkey, yet still all over the world, since unionism is socialism oriented ideology in origin and it is an upheaval against capitalism, therefore, those governments, adapting these viewpoints radically or social democrat standings in a way, are quite eager to restructure their labor markets in line with the unions. On the other hand, economic crisis are the other factors for the establishment of trade unions, which push the policies to change as well. As an example, the Great Depression in 1929, Oil Crisis in 1973, and acceleration of neoliberalism with globalization in 1980s have caused some ups and downs for trade union associations.

These political and economic turning points in a global manner have left a great impact on Turkish labor markets as well. To illustrate, in pre-republican period, socialism as a political action has brought about "awakening" in Ottoman labor markets which resulted in the effectuation of Ottoman Labor Association (Osmanlı Amele Cemiyeti) in 1894 and Ottoman Strike Law (Tatil-i Esgal) in 1908/1909 in spite of restricted number of industrial workers and factories compared to the West. In addition, the economic hassles like Black Thursday in 1929 shifted the economic policy of Turkish state from liberal to Keynesian one till 1973 Oil Crisis on which neoliberal perspectives came to the fore.

In overall, as a result of the study, it can be debated that labor films actually depict the labor formation and unionism (Answer to RQ1), the sine qua non of trade unionism in Turkey are "wage increase", "collective action", "legal rights of labor", "strike", "unite”, and "bargaining” (Answer to RQ2), and the movies can be used for labor market studies (Answer to RQ3). Also, the study contributes to relevant literature in some specific ways. First and foremost, the sine qua non of 
labor markets like "unionism" and "labor" are put into analysis on the basis of a fundamental film

which has strengthened the idea that movies can be used as supplementary items for social sciences. Second, the study contributes to the relevant literature through its qualitative nature, which has been built on MAXQDA 2018. Last but not least, the study underlines and X-rays the typical creation of Turkish labor and their professional marketization process. The sole limitation of the study is the analysis of a "single" film. For future studies, several Turkish labor films like, “Ayrilan Yollar (Departing Ways, 1962), Karanlikta Uyananlar (Those Waking up in the Darkness, 1964), Maden (Mine, 1978), Demiryol (Railway, 1980)", and Cark (Mill, 1987) can be examined.

\section{BIBLIOGRAPHY}

Agha, A. (2007). Language and social relations. Cambridge: Cambridge University Press.

Agha, A. (2011). Meet mediatization. Language Communication, 31, 163-170.

Akkaya, Y. (2010). Cumhuriyet'in Hamallari İsciler, İstanbul: Yordam Kitap.

Arnakis, G. G. (1953). Futuwwa Traditions in the Ottoman Empire Akhis, Bektashi Dervishes, and Craftsmen. Journal of Near Eastern Studies, 12(4), 232-247.

Bairoch, P. (1988). Cities and Economic Development: From the Dawn of History to the Present. University of Chicago Press, Chicago.

Banks, M., \& Hesmondhalgh, D. (2016). Internationalizing Labor Activism: Building Solidarity among Writers' Guilds. In Curtin M. \& Sanson K. (Eds.), Precarious Creativity: Global Media, Local Labor, (pp. 267-280). University of California Press. 
Barton, E. (2002). Resources for discourse analysis in composition studies. Style, 36(4), 575-594.

Berberoglu, B. (1980). State capitalism and national industrialization in Turkey. Development and Change, 11(1), 97-121.

Blumin, S. M. (2006). Driven to the City: Urbanization and Industrialization in the Nineteenth Century. OAH Magazine of History, 20(3), 47-53.

Bodenhorn H. \& Cuberes, D. (2018). Finance and urbanization in early nineteenth-century New York, Journal of Urban Economics, 104, 47-58.

Braudel, F. (1967). Capitalism and Material Life 1400-1800. New York.

Breebaart, D. A. (1972). The" Fütüvvet-name-i kebir". A manual on Turkish guilds. Journal of the Economic and Social History of the Orient, 1, 203-215.

Budeli, M. (2012). Trade unionism and politics in Africa: the South African experience. Comparative and International Law Journal of Southern Africa, 45(3), 454-481.

Castillo, G. (1997). Soviet orientalism: socialist realism and built tradition. Traditional Dwellings and Settlements Review, Vol 8, No 2, 33-47.

Caya, S. (2015). On Strong, Resolute Labor Union Leaders. Procedia-Social and Behavioral Sciences, 190, 559-568.

Celasun, M. (1994). Development Policy and Industrialization in Turkey. International Journal on World Peace, 41-57.

Ceyhun, F. (1988). The politics of industrialization in Turkey. Journal of contemporary Asia, $18(3), 333-357$. 
Claval, P. (1988). European rural societies and landscapes, and the challenge of urbanization and industrialization in the nineteenth and twentieth centuries. Geografiska Annaler: Series B, Human Geography, 70(1), 27-38.

D'Arcy, F. (1971). The Trade Unions of Dublin and the Attempted Revival of the Guilds: An Episode in Mid-Nineteenth Century Irish Labour History. The Journal of the Royal Society of Antiquaries of Ireland, 101(2), 113-127.

Kingsley, D. (1966). "The Urbanization of the Human Population", Ekistics, Vol 21, No 122, Urbanization and Metropolitan Planning, 4-7.

Durkheim, E. (1895-1896), Socialism, translated from the French by Sattler, C., Collier Books, New York.

Ekin, N. (1986). Türkiye'de Endüstri İlişkilerinin Gelişimi ve 1936 İş Kanunu. Sosyal Siyaset Konferanslart Dergisi, 33-51.

Elliott, J. E. (1992), "Socialism and Its Future in the Post-Soviet Era", International Journal of Social Economics, 19(7/8/9), 25-36.

Fizer, J. (1975), "Some observations on the alleged classicism of socialist realism", Studies in Soviet Thought, Vol 15, No 4, pp. 327-337.

Friedman, S. (2012). Democracy in Action: Democratic Theory and Trade Unionism. International Union Rights, 18(4), 18-19.

Goldstein, S., \& Goldstein, A. (1984). Population movement, labor force absorption, and urbanization in China. The Annals of the American Academy of Political and Social Science, 476(1), 90-110.

Güney, A., \& Aslanova, K. (2014). Türk Hukuku'nda Grev Yasakları ve ILO Normları. Calisma ve Toplum, 40(1). 257-272.

Gürsoy, A. K. Ç. A., \& Demirpolat, A. (2003). Heterodoxy-Orthodoxy Tartışmaları ve Türk Fütüvvet Teşkilatı (Ahilik). Selçuk Üniversitesi Sosyal Bilimler Enstitüsü Dergisi, (10), 203-214. 
Habib, H. (1951). Industrialization in Turkey. Pakistan Horizon, 4(1), 40-51.

Hagedorn, R. B., Miller, J. P., \& Labovitz, S. (1971). Industrialization, urbanization and deviant behavior: examination of some basic issues. Pacific Sociological Review, 14(2), 177-195.

Hale, W. (1980). Ideology and economic development in Turkey 1930-1945. British Journal of Middle Eastern Studies, 7(2), 100-117.

Harris, C. D. (1971). Urbanization and population growth in the Soviet Union, 1959-1970. Geographical Review, 102-124

Hechter, M. (1994), "Theoretical Implications of the Demise of State Socialism", Theory and Society, Special Issue on the Theoretical Implications of the Demise of State Socialism, Vol 23, No 2, 155-167.

Hemmerijckx, R. (2001). The Past and Future of International Trade Unionism. International Labor and Working-Class History, 59, 124-125.

Hicks, John. R. (1969). A theory of economic history. OUP Catalogue.

Hiramoto, M., \& Park, J. S. Y. (201). Introduction: media intertextualities: semiotic mediation across time and space. Pragmatics and Society. 1(2), 179-188.

Huff, G., \& Angeles, L. (2011). Globalization, industrialization and urbanization in pre-World War II Southeast Asia. Explorations in Economic History, 48(1), 20-36.

Irwin, R. (2004). " Futuwwa": Chivalry and Gangsterism in Medieval Cairo. Muqarnas, 21, 161170.

Jiang, Z., \& Lin, B. (2012). China's energy demand and its characteristics in the industrialization and urbanization process. Energy Policy, 49, 608-615. 
Johnson, Sally, Astrid Ensslin, (2007). Language in the media: theory and practice. In: Sally Johnson, Astrid Ensslin (Eds.). Language in the media: Representations, Identities, Ideologies, (pp.3-22). London: Continuum.

Karakisla, Y. S. (1992). The 1908 Strike Wave in the Ottoman Empire. Turkish Studies Association Bulletin, 16(2), 153-177.

Kavzoglu, T. (2008). Determination of environmental degradation due to urbanization and industrialization in Gebze, Turkey. Environmental Engineering Science, 25(3), 429-438.

Kaya, Y. (2008). Proletarianization with polarization: Industrialization, globalization, and social class in Turkey, 1980-2005. Research in Social Stratification and Mobility, 26(2), 161-181.

Keles R. (2010). Kentleşme Politikası [Urbanization Policy], Güncellenmiş 11. Baskı, İmge Kitabevi, Ankara.

Kepir-Sinangil, H. (1994). Cultural Transformation and Industrialization in Turkey. International Journal on World Peace, 59-66.

Kim, S. (2005). Industrialization and urbanization: Did the steam engine contribute to the growth of cities in the United States?. Explorations in Economic History, 42(4), 586-598.

Kirkham, P. (1982). Part I Furniture-Makers and Trade Unionism: The Early London Trade Societies. Furniture History, 18, 1-10.

Kocak, H. (2008). 50’leri İşçi Sınıfı Oluşumunun Kritik Bir Uğrağı Olarak Yeniden Okumak. Çalışma ve Toplum, 18, 69-85.

Kocer, R. G. (2007). "Trade Unions at Whose Service?" Coercive Partnerships and Partnership in Coercion in Turkey's Metal Sector. Industrielle Beziehungen/The German Journal of Industrial Relations, 245-269.

Kurucu, Y., \& Chiristina, N. K. (2008). Monitoring the impacts of urbanization and industrialization on the agricultural land and environment of the Torbali, Izmir region, Turkey. Environmental Monitoring and Assessment, 136(1-3), 289-297. 
Lewis, B. (1937). The Islamic Guilds. The Economic History Review, 8(1), 20-37.

Lewis, W. D. (1989). Industrialization and Urbanization-The SENCSA Conference, University of Alabama at Birmingham, April 1987. Technology and Culture, 30(3), 628-634.

Lewis, W.A., (1954). Economic development with unlimited supplies of labour. The Manchester School 22, 139-191.

Lucassen, J., De Moor, T., \& Van Zanden, J. (2008). The Return of the Guilds: Towards a Global History of the Guilds in Pre-industrial Times. International Review of Social History, 53, 5-18.

Macdonald, M. (2003). Exploring Media Discourse. London, England: Arnold.

Madichie, N. O. (2011). Marketing Senegal through hip-hop-A discourse analysis of Akon's music and lyrics. Journal of Place Management and Development, 4(2), 169-197.

Mahirogullari, A. (2001). Türkiye'de Sendikalaşma Evreleri ve Sendikalaşmayı Etkileyen Unsurlar. Cumhuriyet Üniversitesi Iktisadi ve İdari Bilimler Dergisi, (1), 161-190.

Makal, A. (2004). Cumhuriyetin 80. Yılında Türkiye'de Çalışma İlişkileri. Sosyal Siyaset Konferanslarl Dergisi, (47), 123-172.

Mamuti, A. (2013). An Essay on Economic Values of Akhism, Epiphany, Journal of Transdisciplinary Studies, 6(1), 238-246.

Martin, J. (1911). An Attempt to Define Socialism, The American Economic Review, 1(2, Papers and Discussions of the Twenty Third Annual Meeting), 347-354.

Mastboom, J. (1994). Guild or Union? A Case Study of Rural Dutch Weavers, 1682-1750. International Review of Social History, 39(1), 57-75.

McHale, V. E., \& Johnson, E. A. (1977). Urbanization, Industrialization, and Crime in Imperial Germany: Part II. Social Science History, 1(2), 210-247. 
Mendels, F. F. (1972). Proto-industrialization: the first phase of the industrialization process. The Journal of Economic History, 32(1), 241-261.

Millen, B. H. (1969). Factions of the Turkish Labor Movement Differ over Political Role. Monthly Labor Review, 31-35.

Mithun, M. (2018). Discourse and grammar. In D. Tannen, H. E. Hamilton, \& D. Schiffrin (Eds.), The Handbook of Discourse Analysis, (2nd ed.). London, England: Bloomsbury Publishing, 1141.

Moir, H. (1976). Relationships between urbanization levels and the industrial structure of the labor force. Economic Development and Cultural Change, 25(1), 123-135.

Mokyr, J. (1980). Urbanization and Labor Markets in Developing Countries. By Stuart W. Sinclair. Journal of Regional Science, 20(1), 115.

Ocü, A. (1988). The politics of the urban land market in Turkey: 1950-1980. International Journal of Urban and Regional Research, 12(1), 38-64.

Oguz, G. (1995). Recent Industrialization Experience of Turkey in a Global Context. The American Journal of Economics and Sociology, 54(3), 369-371.

Okcün, A. G. (1982) Ta’til-i Eşgal Kanunu 1909 Belgeler-Yorumlar, Ankara: Ankara Üniversitesi Siyasal Bilgiler Fakültesi Yayınları.

Oliveira, Mírian \& Bitencourt, Claudia \& Santos, Ana \& Teixeira, Eduardo. (2015). Thematic Content Analysis: Is There a Difference Between the Support Provided by the MAXQDA® and NVivo ${ }^{\circledR}$ Software Packages?. Revista de Administração da UFSM. 9(1). 72-82.

Ozer, I. (2004). Kentleşme, Kentlileşme ve Kentsel Değişme [Urbanization, Urbanize, Urban Change], Ekin Yayınevi.

Penninx, R. (1982). A critical review of theory and practice: the case of Turkey. International Migration Review, 781-818. 
Pouncy, C. (2005), "Stumbling toward socialist realism: ballet in Leningrad, 1927-1937”, Russian History, Vol 32, No 2, 171-193.

Reeves, S., Kuper, A., \& Hodges, B. D. (2008). Qualitative research methodologies: ethnography. BMJ: British Medical Journal (Online), 337, 570-572.

Reiss Jr, A. J. (1954). Economic growth and the rate of urbanization: a comment on the paper by Davis and Golden. Economic Development and Cultural Change, 3(1), 27-29.

Rogachevskii, A. (1997), "Precursors of socialist realism: Vasili Sleptsov's "trudnoe vremia" and its anti-nihilist opponents", The Slavonic and East European Review, Vol 75, No 1, 36-62.

Rosenberg, N., Trajtenberg, M., (2004). A general purpose technology at work: the Corliss steam engine in the late-nineteenth-century United States. Journal of Economic History, 64 (1), 61-99. Salinger, G. (1950). Was the Futūwa an Oriental Form of Chivalry? Proceedings of the American Philosophical Society, 94(5), 481-493.

Scott, A. J. (1986). Industrialization and urbanization: a geographical agenda. Annals of the Association of American Geographers, 76(1), 25-37.

Speare Jr, Alden, L., Paul, K. C, \& Tsay, Ching Lung (1988). Urbanization and development: the rural-urban transition in Taiwan, Westview Press, USA.

Taeschner, F. (1953). İslam Ortaçağında Futuvva (Fütüvvet Teşkilatı). Ístanbul Üniversitesi İktisat Fakültesi Mecmuası, 15(1-4), 3-32.

Terras, V. (1979), "Phenomenological Observations on the Aesthetics of Socialist Realism", The Slavic and East European Journal, Vol 23, No 4, 445-457.

Therborn, G. (1980). The Ideology of Power and the Power of Ideology, Verso, London.

Tokol, A. (2014). “Sosyal Politikanın Tarafları”, in Sosyal Politika, Tokol A. and Alper. Y. (Ed.), Bursa: Ekin Yayincilik, 5. Baski, 75-97. 
Toprak, Z. (1993) “Amele-i Osmani Cemiyeti,” Dünden Bugüne Ístanbul Ansiklopedisi, Cilt. I, İstanbul, Türkiye Ekonomik ve Toplumsal Tarih Vakfi.

Tso, S. (1927). The Unionization of Labor in China. Monthly Labor Review, 25(5), pp. 16-29.

URL 1 2018, http://www.sinematurk.com/film/3002-diyet/ (Accessed November 07, 2018).

Walton, J., \& Sween, J. A. (1971). Urbanization, industrialization and voting in Mexico: a longitudinal analysis of official and opposition party support. Social Science Quarterly, 721-745.

Walton, Sara, \& Boon, Bronwyn. (2014). Engaging with a Laclau \& Mouffe informed discourse analysis: a proposed framework. Qualitative Research in Organizations and Management: An International Journal, 9(4), 351-370.

Wannöffel, M. (2011). Trade unions in Turkey: Past, Present and Future Developments. SEER: Journal for Labour and Social Affairs in Eastern Europe, 545-569.

Western, B., \& Rosenfeld, J. (2011). Unions, norms, and the rise in US wage inequality. American Sociological Review, 76(4), 513-537.

Williamson, Jeffrey G., (1991). The macroeconomic dimensions of city growth in developing countries: past, present, and future. Proceedings of the World Bank Annual Conference on Development Economics, 241-266.

Yentürk-Coban, N. (1992). Industrialization strategies, foreign trade regimes and structural change in Turkey 1980-8. Foreign trade reforms and development strategy, 274-89.

Yildirim, O. (2002). Ottoman Guilds as a Setting for Ethno-Religious Conflict: The Case of the Silk-thread Spinners' Guild in Istanbul. International Review of Social History, 47(3), 407-419.

Yildirim, O. (2008). Ottoman Guilds in the Early Modern Era. International Review of Social History, 53(S16), 73-93.

Yüksel, H. (2017a), Calisma Yasaminda Sinema, Bursa: Ekin Yayincilik. 
Yüksel, H. (2017b). The Impact of Motherland Party's Neoliberal Policies on Labour Markets within the Framework of 3Ds in New Work Life. Sosyal Bilimler Arastirmalari Dergisi, 7(2), 255268.

Yüksel, H. (2018). Cold War Ideology: The Rocky 4 Movie, Journal of Labor and Society, 21(3), $385-414$.

\section{ENDNOTES}

${ }^{1}$ Theoretically, socialist realism is defined in various ways such as "the essence of which lies in true, historically concrete reflections of reality, taken in its revolutionary development-in the movement of society toward Communism" (Fizer, 1975: 327), "the signifier of a domain assembled by force and legitimized by a myth of a modernizing 'mission civilisatrice' that was reflected in the reform of the built environment" (Castillo, 1997: 33), "a truthful reflection of life in its entirety: not only of its empirical facts, but also of the ideal, inner links between Life's various phenomena" (Terras, 1979: 445), "requires, first and foremost, an extensive re-examination of its cultural and historical roots" (Rogachevskii, 1997: 36), "cultural revolution from 1928 to 1931 [...] as it affected literature, theater, cinema, music, and the fine arts and have uncovered general trends involving culture as a whole" (Pouncy, 2005: 172).

${ }^{2}$ According to the Akkaya's (2010) views based upon his analysis on the Ottoman formal documents, there were 28 strikes determined in Istanbul in 1908 ranging from bakery workers to the mining ones. For example, Balatkapisi Bakery Workers Strike (17 April 1908), Pasabahce Workers Strike (10 May 1908), Rihtim Coal Workers Strike (12 May 1908), Sirket-i Hayriye Hasköy Factory Workers Strike (9 June 1908$)$, Reji Workers Strike (10 June 1908), Halic Coal Workers Strike (12 June 1908), Reji Workers Strike (12 June 1908), Harbor Workers Strike (12 June 1908), Rihtim Workers Strike (12 June 1908), Rihtim and Harbor Workers Strike (12 June 1908), İstinye Linerdop Cement Workers Strike (19 June 1908), Reji Workers Strike (20 June 1908), Coal Workers, Carrying Coals to Ferries, Strike (20 June 1908), Beyoglu Bakery Workers Strike (23 June 1908), Pasabahce Workers Strike (24 June 1908), Anatolian Simendifer Workers Strike (26 June 1908), Bakery Workers Strike (26 June 1908), Bakery Workers Strike (26/27 June 1908), Istabl-i Amire Workers Strike (27 June 1908), Cooks Strike (28 June 1908), Anatolian Simendifer Workers Strike (29/30 June 1908), Rumelia Simendifer Workers Strike (30 June 1908), Bakirkoy Basimhane Workers Strike (1 July 1908), Rumelia Simendifer Yedikule Factory Workers Strike (1 July 1908), Rihtim Company Strike (3 July 1908), Kazlicesme Debbaghane Workers Strike (3/4 July 1908), Anatolian Simendifer Workers Strike (13/14 July 1908), and Tramway Company Workers Strike (15 July 1908) can be included as the strikes taking place mainly and solely in Istanbul (Akkaya, 2010: 48). To my perspective, these strikes possess three characteristics: Ottomans do not have capital accumulations in western standards owing to the fact that industrialization is meagre and state oriented (i). Limited industrial initiatives also hampered the crystallization of mass workers (ii). These strikes also unveil the fact that Ottoman trade unionism is not institutionalized and organized, rather it is local, sectoral, or regional.

${ }^{3}$ See Figure 4 for Codes and Subcodes of the Study. 